\title{
DISTRIBUTION OF BLOOD GROUP TYPE IN DIAGNOSED NS1 Ag POSITIVE DENGUE PATIENTS IN HYDERABAD, TELENGANA STATE, INDIA.
}

\section{Pathology}

Adiba Siddiqui*

Post Graduate, Department of Pathology, Deccan College Of Medical Sciences, Hyderabad , Telengana. *Corresponding Author

Nabiha Tabassum $33^{\text {rd }}$ year MBBS, , Deccan College Of Medical Sciences, Hyderabad, Telengana.

Nabila Afsar

\section{Idrees Akhter} Afroze
Associate Professor, Department of Pathology, Deccan College Of Medical Sciences, Hyderabad, Telengana.

Professor, Department of Pathology, Deccan College Of Medical Sciences, Hyderabad, Telengana.

\section{ABSTRACT}

The aim of this study was to determine the distribution of blood group type in diagnosed NS1Ag positive dengue cases. TheABO phenotypes were identified by use of blood from patients with dengue virus infection prospectively, in newly diagnosed patients at a tertiary care hospital in south India. A total of $162 \mathrm{NS} 1 \mathrm{Ag}$ positive cases were collected with dengue illness. The greatest number $(25 \%)$ of dengue cases were seen in the $11-20$ year age group. Males were predominantly effected( $58 \%)$.It was found that majority $(45 \%)$ of cases belonged to blood groupO.

\section{KEYWORDS}

Dengue fever, NS1 antigen, Blood groups.

\section{INTRODUCTION:}

Dengue fever is a tropical disease caused by Dengue virus belonging to family Flaviviridae, an Arthropod borne disease. Virus is widely distributed throughout the world in tropics and subtropics [1]. Aedes egypti, the urban yellow fever mosquito is the principal vector [2]. Four stereotypes of virus exist referred to as DEN-1, DEN-2, DEN-3, DEN-4 [3]. DV is positive stranded encapsulated RNA virus composed of 3 genes coding for core protein $(\mathrm{C})$, a membrane (M) protein, envelope(E) protein and 7 non-structural(NS) protein[4].All the four stereotypes can cause full spectrum of diseases ranging from dengue fever to fatal dengue hemorrhagic fever.

The blood group $\mathrm{ABO}$ antigens are carbohydrate in nature; the immune dominant sugar in the case of the A determinant is $\mathrm{N}$-acetyl-Dgalactosamine, and that in the case of the B determinant is D-galactose. Galactosyltransferases are involved in the synthesis of these carbohydrate[5]. The antibody that recognizes these carbohydrates is primarily natural IgM. Interestingly, several dengue viral proteins have been shown to be glycosylated, and antibodies, particularly IgM, produced in patients with dengue-virus infection have been shown to cross-react with host cells [6]. Therefore, the results of present study suggest that blood $\mathrm{O}$ is the risk factor for dengue infection. It is also the most frequent position of $\mathrm{ABO}$ blood group system among the blood donors in Hyderabad, Telengana state, India[7].

\section{MATERIALS AND METHODOLOGY}

The study was carried over one year (May2018toJune2019), 162 NS1Ag positive subjects were studied. The data collected included date of admission, age, gender, laboratory investigations. Prospective cases were patients attending outpatient department and patients admitted for dengue. According to the protocol of the hospital, samples for the blood group testing were send from all the diagnosed dengue pateints. Blood samples were collected under aseptic precautions by venipuncture from children and adults with acute febrile illness [8]. Serum was separated by centrifuging samples at $3000 \mathrm{rpm}$ for 5 minutes and tested using tube method. In tube method, three test tubes labeled as A,B,O containing patients serum,one drop of commercially available antisera $\mathrm{A}$, antisera $\mathrm{B}$ were added to the respective tubes and checked for agglutination and results were noted. All the samples showing $\mathrm{O}$ blood group with agglutination were tested for Bombay blood group by slide and tube methods.In slide method,one drop of commercially available anti-H and negative control normal saline) were placed on slide,mixed and checked for agglutination.In tube method,one drop of anti- $\mathrm{H}$ lectin and one drop of 5\% redcell suspension,washed in isotonic saline solution were mixed,shaken to homogenize, centrifuged and checked for agglutination under microscope. Standard hemagglutination assay were used to type the blood groups. The standard method we use is the test tube method not the slide method. Data of 162 samples was compiled in Microsoft Excel.
To minimize the risk of infection, safe laboratory techniques (i.e. use of personal protective equipment, appropriate containers for collection and transportation of samples, etc.) were practiced as described in WHO's laboratory biosafety manual [9]. Acute dengue-virus infections were diagnosed (by ELISA and NS1+Ag test) [10]

\section{RESULT}

Table-1: Percentage distribution of dengue among Male and Female

\begin{tabular}{|c|c|c|}
\hline Sex & $\begin{array}{c}\text { Number of individuals } \\
\text { Affected }\end{array}$ & $\begin{array}{c}\text { \% of individuals } \\
\text { Affected }\end{array}$ \\
\hline Female & 67 & $42 \%$ \\
\hline Male & 95 & $58 \%$ \\
\hline Total & 162 & $100 \%$ \\
\hline
\end{tabular}

Table 1: shows the gender distribution of dengue patients under study. 95 case were male $(58 \%)$ and $67(42 \%)$ females were affected with dengue illness. Hence males are more affected than females.

Table-2 : Age distribution of dengue illness.

\begin{tabular}{|c|c|c|}
\hline Age group & $\begin{array}{c}\text { Number of individuals } \\
\text { affected }\end{array}$ & $\begin{array}{c}\text { \% of affected } \\
\text { Individuals }\end{array}$ \\
\hline $0-10$ & 37 & $23 \%$ \\
\hline $11-20$ & 41 & $25 \%$ \\
\hline $21-30$ & 39 & $24 \%$ \\
\hline $31-40$ & 19 & $12 \%$ \\
\hline $41-50$ & 9 & $6 \%$ \\
\hline $51-60$ & 8 & $5 \%$ \\
\hline $61-70$ & 7 & $4 \%$ \\
\hline $71-80$ & 1 & $1 \%$ \\
\hline $91-100$ & 1 & $1 \%$ \\
\hline Total & 162 & $100 \%$ \\
\hline
\end{tabular}

Table -2 shows age distribution of dengue infection. Majority of dengue illness were between the age group of 11-20 years $(25 \%)$, followed by $21-30$ years $(24 \%)$ and $0-10$ years $(23 \%)$.

Table-3: Distribution of dengue among different blood group and Rh types.

\begin{tabular}{|c|c|c|}
\hline $\begin{array}{c}\text { ABO \& } \\
\text { Rh type }\end{array}$ & Number of cases & $\begin{array}{c}\text { Percentage of individuals } \\
\text { Affected }\end{array}$ \\
\hline $\mathrm{A}+\mathrm{ve}$ & 12 & $7 \%$ \\
\hline $\mathrm{A}-\mathrm{ve}$ & 0 & $0 \%$ \\
\hline $\mathrm{B}+\mathrm{ve}$ & 59 & $37 \%$ \\
\hline $\mathrm{B}-\mathrm{ve}$ & 3 & $2 \%$ \\
\hline $\mathrm{AB}+\mathrm{ve}$ & 12 & $8 \%$ \\
\hline $\mathrm{AB}-\mathrm{ve}$ & 0 & $0 \%$ \\
\hline $\mathrm{O}+\mathrm{ve}$ & 72 & $44 \%$ \\
\hline
\end{tabular}




\begin{tabular}{|c|c|c|}
\hline O-ve & 4 & $2 \%$ \\
\hline Bombay & 0 & $0 \%$ \\
\hline Total & 162 & $100 \%$ \\
\hline
\end{tabular}

Table-3 depicts distribution of dengue among different blood groups and $\mathrm{Rh}$ type. It was found that o blood group was predominant, followed by B (38\%) and A (7\%)

\section{DISCUSSION}

Dengue fever, an acute febrile arbo-viral disease has become a major public health problem in tropical and subtropical regions of the world, especially in India. Hence, a clinical study of the dengue cases was done to analyze the blood group at risk and prevent the disease. The results of the present study suggest that blood group $\mathrm{O}$ may be a risk factor predisposing for dengue disease.

In studies carried out by Kalayanauroojet al [11] and Khodeet al.,[12] O blood group was the predominant, hene this finding was comparable with the present study. Hence people with Type O blood are found to be more attractive to mosquitoes than those with Type A blood. Also, blood group $\mathrm{O}$ distribution was consistent with Indian population which could have been a confounding factor. Studies in the Southern India described ' $\mathrm{O}$ ' as the most frequent and ' $\mathrm{B}$ ' as the second most common blood group[13] [14] [15] [16]. Studies confirmed that O group is the most frequent position of ABO blood group system among the blood donors in Hyderabad, Telangana state, India [7].

In studies carried out by Attiya et al[17],Ashraf Khaskheli et al [18] and Nadeem Afraz et alI[19], stated that males were effected more than the females. The results of these studies were similar to the present study. Male gender was predominant which may be attribuited to the fact that in Asian culture, males spend more time outside their houses and thus are more likely to be exposed when compared to females[20],[21]. Also there has been a growing recognition that biological differences between male and female based on genetic, immunological and hormonal factors, may determine the susceptibility to disease and clinical outcome, including for dengue infection.[22],[23], Females may mount a more vigourous immune response to infection than males[24].

Therefore, the results of the present study suggest that blood group $\mathrm{O}$ is the risk factor.

Because of the limitations of the sample size in the present study, further studies may be conducted during subsequent dengue season to determine whether dengue and $\mathrm{ABO}$ are independent variables and severity of dengue in relation to blood groups needs to be assessed.

\section{CONCLUSIONAND SUGGESTIONS}

- Blood groupO individuals must exercise extra caution compared to the general population since $\mathrm{O}$ group are more prone to develop dengue.

- Personal prevention consists of reducing the outdoor time and hence preventing the exposure to mosquitoes. Use of mosquito nets on windows, repellants, use of DEET-impregnated bed nets, and avoiding endemic areas.Avoiding stagnation of water around the house. Application of larvicides to items such as buckets, gutters, septic tanks etc.

\section{REFERENCES:}

1. RAnanthanarayan and JC Paniker, (2017) Dengue Virus. Arthropod-And Rodent-borne RAnanthanarayan and JC Paniker, (2017) Dengue Virus. Arthropod-
ViralInfections, Text book of Microbiology,10th edition p 529-01.

2. Wikipedia. Aedesaegypti.available from: URL; https:// en.wikipedia.org/ wiki/Aedes aegypti

3. Normile D (October 2013). "Tropical medicine. Surprising new dengue virus throws a spanner indisease control efforts". Science. 342 (6157): 415. doi:10.1126/ science. 342. 6157.415. PMID 24159024.

4. RAnanthanarayan and JC Paniker, (2017) Dengue Virus. Arthropod- And Rodent-borne ViralInfections, Text book of Microbiology,10p 529-07.

5. Greenwell P. Blood group antigens: molecules seeking a function?,Glycoconj J, 1997, vol. 14(pg. 159-73)

6. Guzman MG. Global voices of science, Deciphering dengue: the Cuban experience, 2005, vol. 309 Science (pg. 1495-7)

7. Sanagapati PR, Vujhini SK. ABO and Rh-D blood group frequency and distribution: a tertiary care hospital experience. Int J Res Med Sci 2015;3(8):2058-61.

8. Kalayanarooj S, Vaughn DW, Nimmannitya S, et al. Early clinical and laboratory indicators of acute Dengueillness, J Infect Dis, 1997, vol. 176 (pg. 313- 21) Google Scholar Crossref http://adsabs.harvard.edu/cgi-bin/basic connect? qsearch $=10.1086 \%$ 2Fjid.1997.176.issue-2 [PubMed]

9. WHO. Laboratory biosafety manual. 3rd ed. Geneva: World Health Organization; 2004 (ISBN $9241546506, \mathrm{WHO} / \mathrm{CDS} / \mathrm{CSR} / \mathrm{LYO} / 2004.11 \mathrm{http}: / /$ www.who.int/ csr/ resources/publications/biosafety/Biosafety7.pdf.

10. Vazquez S, Fernandez R, Llorente C. Usefulness of blood specimens on paper strips for serologicstudies with inhibition ELISA. Revista do Instituto de Medicina Tropical de
São Paulo. 1991;33(4):309-311. [PubMed]

11. Kalayanarooj S, Gibbons RV, Vaug D, Green S, Nisalak A, Jarman RG, et al. Blood Group $\mathrm{AB}$ is associated with risk for severe dengue disease in secondary infections. J Infect Dis 2007;195:1014-7.

12. Khode V, Kabbin G, Ruikar K. Association of ABO Rh blood group with dengue fever and dengue hemorrhagic fever: A case-control study. J ApplHematol 2013;4:145-8 Available from: http://www.jahjournal.org/text.asp?2013/4/4/145/127899

13. Swamy CMM, Basavaraj PB, Kavitha GU, Shashikala P. Prevalence of ABO and Rhesus blood group among blood donors. Indian Journal of Public Health Research and Development. 2012;3(2):106-09.

14. Pericaval A, Sangeetha SK, Mari Muthu P, Manjunath BK, Seema DM. Distribution of $\mathrm{ABO}$ and Rhesus-D groups in and around Bangalore. Asian J Transfus Sci. 2010;4(1):41.

15. Reddy KS, Sudha G. ABO and Rh (D) blood groups among the DesuriReddis of Chittur District, Andhra Pradesh. Anthropologist.2009; 11:237-8.

16. Das PK, Nair SC, Harris VK, Rose D, Mammen JJ, Bose YN, et al. Distribution of ABO and Rh-D blood groups among blood donors in a tertiary care centre in South India. Trop Doct. $2001 ; 31: 47-8$.

17. Attiya Mehboob Zafar et al. Clinical characteristics of patients with dengue fever Journal Ayub Medical College, Abbottabad. 2010;22(4)

18. Ashraf Khaskhelli Nasreen et al. J LUMHS Sept-Dec. 2010; vol:9 No3

19. Nadeem Afraz, Surriya Amber et al. Prevalance of dengue fever in RawalpindiIslamabad. A cross sectional study: BMJ 2002; 324:1563-1566.

20. Qureshi Ta, Notta N, Salahuddin N, Zaman V. Khan JA: An epidemic of dengue fever in Karachi, associated clinical manifestations. J Pak Med Assoc. 1997; 47:178-181.

21. Rathore K,Misra B, Khaur J, Kakkar N et al. An outbreak of dengue fever in periurban areas of Channdigarh, India with special reference to entomological and climatic factors. Indian Journal of Medical . 2005;59:518-526.

22. White horn J, Simmons CP. The pathogensis of dengue vaccine; 2011. 29:7221-7228.

23. Ander KL et al. Epidemiological factors associated with dengue shock syndrome and mortality in hospitalized dengue patients in Ho Chi Mint City, Vietnam. The American Journal of Tropical 2010.33:278-284.

24. Klein SL.et al. The effect of hormones on sex difference in infection from genes to behavior. Neuroscience and Bibehavioral Reviews, 2000. 24:627-638. 